\title{
DEVELOPING SCALE TO MEASURE STUDENT'S HONESTY CHARACTERS ON MATHEMATICS LEARNING USING SUBJECT SCALING
}

\author{
Kana Hidayati ${ }^{1}$ *, Budiyono ${ }^{2}$, Sugiman ${ }^{1}$ \\ ${ }^{1}$ Universitas Negeri Yogyakarta, ${ }^{2}$ Universitas Sebelas Maret \\ ${ }^{1} J 1$. Colombo No. 1, Depok, Sleman 55281, Yogyakarta, Indonesia \\ ${ }^{2} J 1$. Ir. Sutami No.36 A, Pucangsawit, Jebres, Kota Surakarta, 57126, Jawa Tengah Indonesia \\ * Corresponding Author. Email:kana@uny.ac.id
}

\begin{abstract}
The purpose of this study is to develop a scale to measure honesty characters of students on mathematics learning using sucject scaling model. This development research is carried out in several steps namely: preparing initial scales, trials, and interpretation of trials result. The research is conducted on students of SMP N 5 Yogyakarta, SMP Muhammadiyah 2 Yogyakarta, and SMPIT Abu Bakar Yogyakarta. The first trial involves 688 students and the second trial involves 696 students. Content validity is obtained through expert judgment. The construct validity is determined by Lisrel's second order CFA. Reliability coefficients include Omega coefficients $(\omega)$ and Alpha coefficients from Cronbach. Based on the results of this research, the scale to measure of student's honesty characters consists of 15 items that theoretically and empirically proved to be of good quality. The scale has good content validity supported by $\mathrm{V}$ Aiken index of $0.88-0.92$. The scale has good construct validity. Reliability of the scale is also good supported by both the Omega coefficient of 0.86 .
\end{abstract}

Keywords: honesty character, mathematics, subject scaling

Permalink/DOI: http:/ / dx.doi.org/10.21831/pep.v22i2.19310 


\section{Introduction}

National Education System Indonesia strongly emphasizes education that is able to make Indonesian people not only have intellectual intelligence but also noble character with good spirituality, personality, and selfcontrol. Therefore, character education is highly emphasized in Indonesian education system and continues to undergo reforms following the development of the era.

The implementation of Curriculum 2013 in Indonesia that emphasizes character education and the establishment of the Character Education Strengthening program in schools are several forms of government commitment in order to strengthen the noble character that Indonesian students must possess. It is in line with the statement of Minister of Education and Culture Muhadjir Effendy who mentioned that the portion of science education for junior high school education is $40 \%$ and character education by $60 \%$ (Maharani, 2016).

According to Lickona (1992), good character education emphasize on three groups of good character namely moral knowing, moral feeling, and moral action. Good character education contains knowledge which further raises the commitment to be a good person and finally really embodied in doing good behavior. According to the taxonomy of (Krathwohl, Bloom, \& Masia (1964), this thing corresponds to the affective domain. It becomes the benchmark of attitude competence in the Curriculum 2013 namely receiving, responding, valuing, organization, and characterization by value.

Character education in learning mathematics can be integrated in the form of attitude assessment. That is, through the assessment of attitudes in learning mathematics, character of students can be measured and the results will be very helpful for teachers in order to strengthen good character of the students. Kumaidi (2014) suggest that the Curriculum 2013 requires teachers not only assess the mastery of teaching materials but also include the development of affection such as faith, honesty, discipline, and other good character.
One of the emphasized good character that must be owned by Indonesian students is honesty. Strengthening the honesty character of the students can be integrated into all subjects in school including Mathematics. As one of the material in learning mathematics, statistics is closely related to data in the field. Honesty characters can be developed and strengthened through the learning of statistical materials that are directly applicable in everyday life. Strengthening this honesty character certainly requires accurate information about the actual condition of the honest character of the student. Therefore, the measurement of honest character of students must be done using instruments that are reliable and consistent so that the information obtained from it is truly accurate and can be accounted for.

Measurement of honest character in mathematics learning using the right measurement scale is certainly very helpful for the teacher in assessing the attitude or affective aspects of students. According to Popham (2009, p. 107), affective assessment of students when carried out during school learning activities can contribute to students' behavior after graduation. This means that the measurement and assessment of the honest character of students during school greatly influences student's honest behavior after graduation. Through the measurement and assessment of the honest character done during school, of course, making honest character will be embedded more strongly in students so that it is still carried away even after graduation.

According to the Ministry of Education and Culture (Kementerian Pendidikan dan Kebudayaan Republik Indonesia, 2013), honesty is a behavior based on the effort to make oneself as a person who can always be trusted in words, actions, and work. Asmani (2011) also states that honesty is a behavior that makes oneself as a person who can always be trusted that is manifested in words and actions, both for themselves and for others. In other words, honesty is the character which makes people to act as they are in accordance with the truth, not made up, 
not lying, not reduced, not added to, and not hiding information. If someone says something that it is not in accordance with the truth and the actual reality or does not acknowledge something according to what it is, then that person can be said to be dishonest. Honesty is defined as being honorable in principles, intentions, and actions; being upright, fair, sincere, frank, respectable, and truthful; and free from deceit or fraud (Cherrington \& Cherrington, 1979, p. 645). State that in line with those opinion, Bisri (2009) also state that honesty means saying or acting according to what is actually in accordance with the reality as it is without being reduced or added. The opposite of honesty is a lie, that is to say or do something that is not in accordance with the actual reality.

The characteristics of honest behavior according to Emosda (2011) are that their behavior is followed by a pure or sincere heart, say something according to reality, and act according to the evidence and truth that exists. The indicators of honesty character in education according to the Ministry of Education and Culture (Kementerian Pendidikan dan Kebudayaan Republik Indonesia, 2015) includes: (a) not cheating in doing tests, (b) not doing plagiarism (copying or taking the work of others without mentioning the source), (c) expressing feelings as they are, (d) submit the findings to those who have the right or authority, (e) make reports based on information or data as they are, (f) acknowledge the shortcomings or errors owned, and (g) convey information according to the facts. Koellhoffer $(2009$, p. 4) also stated that honesty in academics means being honest in educational regulations. Someone is said to be academically honest if he does not commit acts of plagiarism. That is, not using someone else's work or not copying someone else's work without his permission. According to Koss (2011, p. 39), academic dishonesty is a behavior or action of someone who borrows and copies assignments from other people, including copying answers at the time of the exam. Other academic dishonesty behaviors are writing test answers on feet or hands, clothes, walls, paper, tables or chairs, and exchanging answers with friends using certain codes.

According to Kibler (Ercegovac \& Richardson, 2004, p. 301), academic dishonesty is a form of plagiarism and fraud committed by students in the form of receiving or giving unauthorized assistance in examinations and receiving awards from another person works. Other dishonest behavior in academic activities is that students take advantage of the opportunities available to exchange answers with their friends or cheat, for example when the examiner exits the room. Schmelkin, Gilbert, Spencer, Pincus, \& Silva (2008, p. 4) argued that forms of academic dishonesty are plagiarism, imitating each other with exams during tests, stealing tests or questions, and buying answer papers. Dishonest behaviour has severe negative consequences for institutions and students. The academic dishonesty violates scientific principles, as well as study and assessment regulations (Bashir \& Bala, 2018, p. 57). Academic dishonesty is clearly an unjustified act in the education system in Indonesia. Based on the various opinions above, it can be concluded that honesty character encompasses several components, namely behaving as they are according to reality, recognizing any positive or negative actions, doing assignments or examinations according to their own abilities, and can be trusted for the ownership of others.

During this time the measurement and assessment of the achievement of competencies for aspects of attitudes related to the level of honest character students in mathematics learning is generally done by observation, interviews, self-assessment, and peer assessment. The form of instruments used mostly in the form of observation sheets, interview guidelines, and questionnaires in the form of response scaling. Character measurement is basically a measurement of an individual's personality so that it requires an instrument that can truly distinguish personality between individuals. Therefore, the use of a scale in the form of subject scaling that is more specific and detailed in 
measuring the character of students needs to be done. However, until now there have not been many studies on the development of a scale to measure the honest character of students, especially in mathematics learning that uses the subject scaling model. In fact, the instrument in the form of subject scaling has high practical value and is widely used by designers of psychological scale (Azwar, 2005 , p. 32). This is also as stated by Punyanunt-Carter $(2017$, p. 34) that a scale centered on a subject which is also called an individual difference scale is very suitable to be used to measure a person's personality.

Based on the description above, this study aims to develop a scale to measure the honesty character of students in learning mathematics. This scale uses the subject scaling model and the quality is tested theoretically and empirically. The research problem is formulated as follows: (1) how the content validity of the scale is used to measure the honesty character of students in learning mathematics; (2) how the construct validity of the scale is used to measure the honesty character of students in learning mathematics; (3) how the reliability of the scale is used to measure the honesty character of students in learning mathematics.

\section{Method}

This research is a development research conducted by several steps: (1) preparing the initial scale, (2) testing, and (3) interpretation of the results of the trial. Arranging the initial scale is the initial activity of developing a scale which is then discussed in Focus Group Discussion (FGD) and followed up with validation through expert judgment. The final validation results are evidence of the validity of the contents of the scale being developed. The next stage is the trial and followed up by the interpretation of the results of the trial, namely determining the evidence of scale quality related to construct validity and scale reliability and determining whether or not revisions and trials are needed.

The FGD activity involved 4 junior high school math teachers and 3 Mathe- matics education lecturers. Scale validation with expert judgment involves six experts who examine the scale in terms of its content, namely: (a) suitability of items with indicators, (b) language used, (c) item statements that are unbiased, (d) clarity of answer choices, and (e) accuracy of scoring guidelines. Experts also assess the suitability between items with indicators in the form of a Likert scale with five answer choices. In this case, the content of social desirability is overcome by writing the items following the standard rules in the preparation of the scale (Azwar, 2005, p. 9). In addition to qualitative assessments from experts, evidence of content validity is also supported by the amount of content validity index using $\mathrm{V}$ Aiken. The way to determine of the validity of an item is to compare the value of $\mathrm{V}$ with the value of $\mathrm{V}_{\text {table. The }} \mathrm{V}_{\text {table }}$ value is the minimum value of the content validity index based on the number of experts in table $\mathrm{V}$ in (Aiken, 1985, p. 134). The number of repeaters in this study were six and the number of ratings was five, so the minimum index of content validity based on V Aiken's table was 0.79 .

The trial was conducted on seventh grade junior high school students in the city of Yogyakarta who had implemented the 2013 Curriculum. The selection of junior high schools where the trial was conducted was purposive cluster sampling technique, which was a trial conducted at junior high schools that represented high, medium, and developing quality and represented public and private schools. Determination of the quality of schools in this study is based on the results of the National Examination. The schools selected as trial sites were SMP N 5 Yogyakarta, SMP IT Abu Bakar Yogyakarta, dan SMP Muhammadiyah 2 Yogyakarta.

The results of the trial data in this study are quantitative data. Data is obtained based on the students' responses on the scale to measure the honesty character of students. Data collection techniques is carried out by giving the scale developed for students to be filled out by the participants of the trial. 
Data analysis begins with test requirements analysis to find out whether the data meets the requirements to be analyzed by the Confirmatory Factor Analysis (CFA) technique, that is, the data to test the model follows a multivariate normal distribution. The criteria used are if the p-value $>0.05$ then the distribution is normal, and if the p-value is 0.05 then the distribution is not normal (Yamin \& Kurniawan, 2009, p. 29).

After testing the requirements analysis, data analysis is carried out to prove the construct validity of the scale through second order CFA with the help of the Lisrel version 8.51 program. Criteria for an indicator item said to be valid in representing the construct is if the t-value is $>1.96$ and the value of Standarized Loading Factor (SLF) is at least 0.3 (Hair, Black, Babin, \& Anderson, 2009; Igbaria, Zinatelli, Cragg, \& Cavaye, 1997, p. 290). Referring to these criteria, if there is an invalid indicator item, the item must be eliminated and re-analyzed. Based on the results of re-analysis after invalid indicator items are eliminated, what needs to be considered is the compatibility with the model. If the model is not fit, the model is then respecificated by modifying the index as suggested by Lisrel.

The suitability of the model in this study refers to Garson (2009) who stated that the suitability of the model developed through empirical data is at least seen from the fulfillment of two of the three different model suitability measurement categories, namely absolute match test, incremental suitability test, and parsimony suitability test. Suranto, Muhyadi, \& Mardapi (2014, p. 102) suggested that the developed model is stated to be compatible with the field data if two criteria have been met from the three criteria that become the absolute compatibility measurement, namely Root Mean Square Error of Approcimation (RMSEA) 80.08, Chisquare obtained from the test has a probability greater than $0.05(\mathrm{p}>0.05)$ and Goodness of Fit Index (GFI) 900.90. In addition, it also refers to the opinions of (Hooper, Couglan, \& Mullen, 2008, p. 57) which suggests that the use of Chi square is sensitive to the sample size used. As according to Wijanto (2008, p. 155) suggests that the consensus of the researchers states that Chi square is not the only measurement of Goodness of Fit (GOF) and there is no particular GOF measurement that exclusively represents the overall suitability of the model. Estimation of reliability is determined by the McDonald's composite reliability coefficient or Omega $(\omega)$ coefficient. This refers to Widhiarso (2009, p. 47) which states that reliability which begins with CFA using SEM in multidimensional measurement models can be done with Omega reliability coefficient $(\omega)$. Reliability coefficient criteria refers to Hair et al. (2009, p. 688), which mentioned that the estimated reliability $>0.7$ is good, while the reliability coefficient $0.6-0.7$ is acceptable as long as the construct validity indicator of the model is good.

\section{Findings and Discussion}

Based on the results of the initial scale's preparation which was then discussed in the FGD and followed up by validation of experts, a scale to measure the honesty character of students consisting of 17 points is arranged. The formulation of the scale items is compiled based on the components and indicators of honest construct as presented in Table 1.

Based on the results of validation the initial scale to measure honesty character of the students through mathematics learning, which is consisting of 17 items in the form of subject scaling, has good content validity so that it is feasible to use. The feasibility of the scale being developed is also supported by the magnitude of the $\mathrm{V}$ Aiken index for the suitability between items with indicators compared with the $\mathrm{V}$ value of 0.79 . Based on the calculation results, the calculated $V$ value in the whole item is $0.88-0.92$. This shows that all items on the scale to measure the honest character of students, have good content validity in terms of their suitability with the indicators. That is, in terms of its contents, the scale to measure the honesty character of students developed through this 
research can be said to measure what should be measured.Top of Form

Table 1. Components and Indicators for Measuring Honesty Character of Students

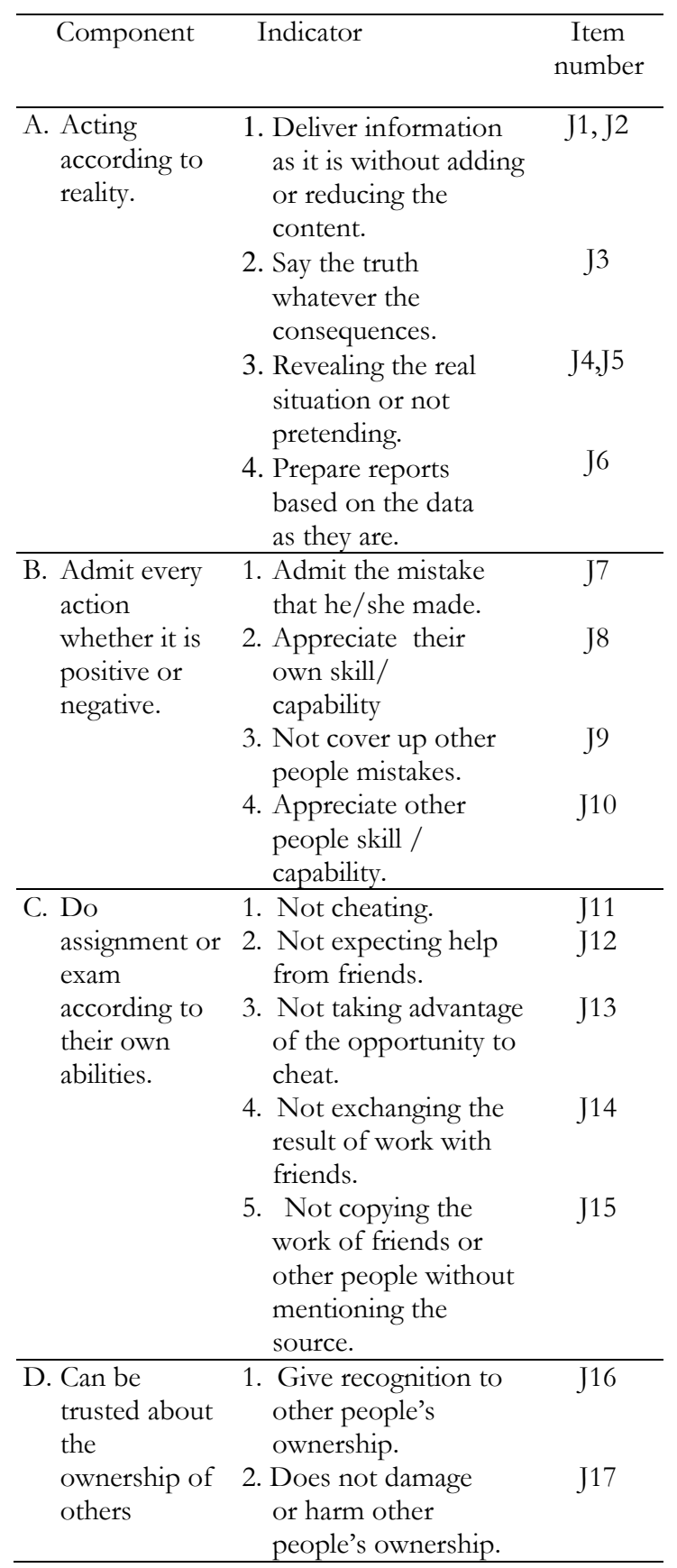

The scale that was declared feasible by the experts was then tested on students of SMP 5 Yogyakarta, SMPIT Abu Bakar Yogyakarta, dan SMP Muhammadiyah 2 Yogyakarta. Trial I involved 688 students. The results of the initial analysis indicate that the data are not multivariate and normally distributed so that the second order CFA analysis is carried out using the Weighted Least Square (WLS) estimation model.

Based on the results of the test data analysis I obtained the Chi Square $=298.98$, $\mathrm{p}=0.00, \quad \mathrm{RMSEA}=0.048, \quad \mathrm{GFI}=0.98$, and AGFI $=0.97$. These results indicate that the suitability of the model can be said to be sufficiently fulfilled. It means that the model is sufficiently compatible with the data. The scale to measure the honesty character of students in the first trial consisted of 17 items in the form of subject scaling. The results of the second order CFA for the value of t-value and Standarized Loading Factor (SLF) for the trial I are presented in Table 2.

Table 2 shows that in terms of the $\mathrm{t}$ value, all items are significant in supporting an honesty construct, but there are four items that have SLF values of less than 0.3 namely points $\mathrm{J} 2, \mathrm{~J} 3, \mathrm{~J} 6$, and $\mathrm{J} 10$. This means that points $\mathrm{J} 2, \mathrm{~J} 3, \mathrm{~J} 6$ and $\mathrm{J} 10$ need to be reviewed.

Table 2. Trial I Result of Second Order CFA

\begin{tabular}{|c|c|c|c|c|c|}
\hline \multirow[t]{2}{*}{ Comp } & \multirow[t]{2}{*}{ Indicator } & \multirow[t]{2}{*}{ Item } & \multicolumn{2}{|c|}{$\begin{array}{c}\text { Second } \\
\text { order CFA }\end{array}$} & \multirow[t]{2}{*}{ Meaning } \\
\hline & & & $\mathrm{t}$-value & SLF & \\
\hline \multirow[t]{6}{*}{$\mathrm{A}$} & A1 & $\mathrm{J} 1$ & $* *$ & 0,36 & Good \\
\hline & A2 & $\mathrm{J} 2$ & 2,61 & 0,14 & $\begin{array}{l}\text { Not good } \\
\text { (must be } \\
\text { revised) }\end{array}$ \\
\hline & A3 & $\mathrm{J} 3$ & 5,03 & 0,29 & $\begin{array}{c}\text { Not good } \\
\text { (must be } \\
\text { revised) }\end{array}$ \\
\hline & A4 & J4 & 6,77 & 0,58 & Good \\
\hline & A5 & $\mathrm{J} 5$ & 5,54 & 0,30 & Good \\
\hline & A6 & J6 & 0,21 & 0,01 & $\begin{array}{c}\text { Not good } \\
\text { (must be } \\
\text { revised) }\end{array}$ \\
\hline \multirow[t]{4}{*}{ B } & B1 & $\mathrm{J} 7$ & $* *$ & 0,75 & Good \\
\hline & B2 & J8 & 16,22 & 0,69 & Good \\
\hline & B3 & J9 & 13,69 & 0,65 & Good \\
\hline & B4 & $\mathrm{J} 10$ & 5,02 & 0,24 & $\begin{array}{l}\text { Not good } \\
\text { (must be } \\
\text { revised) }\end{array}$ \\
\hline \multirow[t]{5}{*}{$\mathrm{C}$} & C1 & J11 & $* *$ & 0,69 & Good \\
\hline & $\mathrm{C} 2$ & J12 & 13,70 & 0,57 & Good \\
\hline & C3 & $\mathrm{J} 13$ & 18,29 & 0,81 & Good \\
\hline & $\mathrm{C} 4$ & $\mathrm{~J} 14$ & 17,64 & 0,80 & Good \\
\hline & C5 & $\mathrm{J} 15$ & 14,11 & 0,59 & Good \\
\hline \multirow[t]{2}{*}{$\mathrm{D}$} & D1 & J16 & $* *$ & 0,68 & Good \\
\hline & D2 & $\mathrm{J} 17$ & 4,95 & 0,54 & Good \\
\hline
\end{tabular}


Points J2, J3, J6 and J10 each represent one indicator. Therefore, these four items are not eliminated but are corrected or revised. After the revision, a trial II was conducted involving 696 students.

The results of data analysis in trial II showed that the data analyzed was not normally distributed multivariate so that the second order CFA analysis was carried out using the Weighted Least Square (WLS) estimation model. Based on the results of the initial analysis in trial II it was found that there were two items that had SLF values less than 0.3 , namely items J2 and J5. Therefore, further analysis is carried out after eliminating items J2 and J5. Further analysis is also carried out by observing the index modifications suggested by Lisrel. Modification of the model as suggested by Lisrel software can be seen in Figure 1.

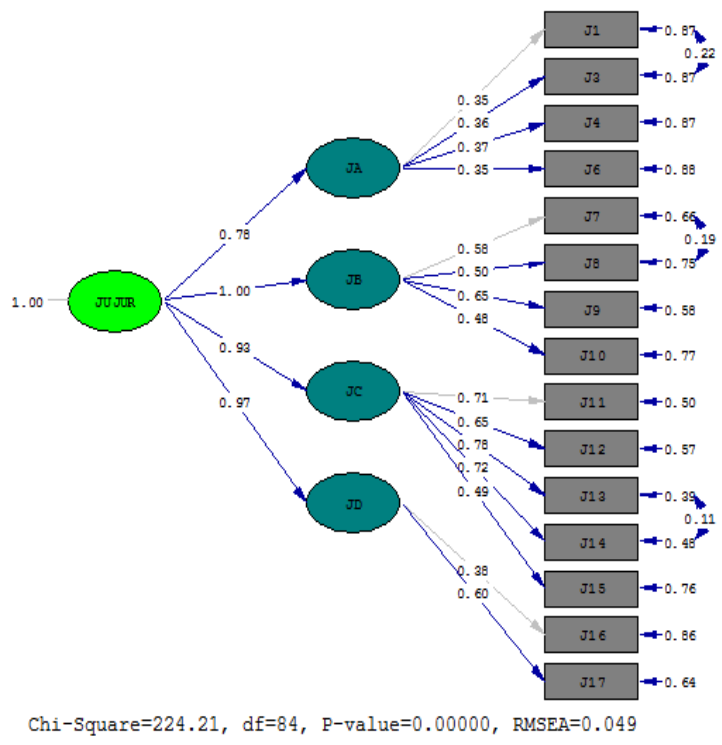

Figure 1. Measurement Model of Scale to Measure Honesty Character

As presented in Figure 1, the modification made by the researcher is to add covariance between two errors in $\mathrm{J} 1$ and $\mathrm{J} 2$, $\mathrm{J} 7$ and J8, J13 and J14. The researchers' considerations that each represents the same latent variable and decreases the chi square value, and it can be supported by strong reason. J1 indicator is to convey information as it is without adding or subtracting and the $\mathrm{J} 2$ indicator is to tell the truth whatever the consequences. J7 indicator is to acknowledge the mistake made and $\mathrm{J} 8$ indicator is to give credit to the strengths of self. As for J13 indicator is not taking advantage of the opportunity to cheat and J14 indicator is not exchanging work results with friends. Pay attention to these indicators, the error that occurs in the J1 indicator is clearly very influential on the $\mathrm{J} 2$ indicator. Likewise for $\mathrm{J} 7$ and $\mathrm{J} 8, \mathrm{~J} 13$ and $\mathrm{J} 14$. It shows that it is reasonable to add covariance between two errors in J1 and $\mathrm{J} 2, \mathrm{~J} 7$ and $\mathrm{J} 8, \mathrm{~J} 13$ and $\mathrm{J} 14$. Based on the results of the final analysis after modification, Chi Square $=224.21, \mathrm{p}=0.00, \mathrm{RMSEA}=$ 0.049 , GFI $=0.98$, and $\mathrm{AGFI}=0.97$ were obtained. This shows that the suitability of the model is sufficiently fulfilled, meaning that the model is sufficiently in accordance with the data. The results of the second order CFA for the value of t-value and Standarized Loading Factor (SLF) are presented in Table 3.

Table 3. Trial II Result of Second Order CFA

\begin{tabular}{ccccc}
\hline Comp & Indicator & Item & \multicolumn{2}{c}{ Second order CFA } \\
\cline { 3 - 5 } & & & t-value & SLF \\
\hline A & A1 & J1 & $* *$ & 0,35 \\
& A3 & J3 & 5,60 & 0,36 \\
& A4 & J4 & 4,64 & 0,37 \\
& A6 & J6 & 4,11 & 0,35 \\
\hline B & B1 & J7 & $* *$ & 0,58 \\
& B2 & J8 & 10,26 & 0,50 \\
& B3 & J9 & 12,05 & 0,65 \\
& B4 & J10 & 8,56 & 0,48 \\
\hline C & C1 & J11 & $* *$ & 0,71 \\
& C2 & J12 & 15,73 & 0,65 \\
& C3 & J13 & 15,58 & 0,78 \\
& C4 & J14 & 16,11 & 0,72 \\
& C5 & J15 & 11,36 & 0,49 \\
\hline D & D1 & J16 & $* *$ & 0,38 \\
& D2 & J17 & 6,42 & 0,60 \\
\hline
\end{tabular}

Table 3 shows that in terms of $\mathrm{t}$-value, all points are significant in supporting an honest construct. When viewed from the SLF value, it also shows that all items meet the criteria of good construct validity.

The reliability coefficient used is Omega reliability coefficient because honest constructs are multidimensional. Based on the calculation results obtained Omega reliability coefficient of 0.86 . These results indi- 
cate that the scale for measuring honest characters has good reliability referring to the criteria of Hair et al. (2009, p. 688). This means that in terms of the construct, the scale for measuring honesty character of students can be said to be reliable or consistent.

Based on the results of the trial II, the final results were obtained in the form of a scale to measure the honesty character of students which is theoretically and empirically proved to be good quality. Theoretically, it is proven by the validity of the content of the scale which shows that the content according to the experts is good and the whole item has a good suitability with the indicator. This is also supported by the magnitude of the V Aiken index of 0.88-0.92. Empirically, in terms of its construct validity, all scale items have good support in establishing an honesty construct that is established. As for the reliability review is also included in the good category with the Omega reliability coefficient of 0.85 . Thus, the final result of the scale development in this study is to obtain a scale to measure the honest character of students through mathematics learning consisting of 15 items in the form of subject scaling.

Writing instrument items in the form of subject scaling is not easy. However, this form is able to reveal students' affective conditions in more depth. This is as stated by Azwar (2005, pp. 29-32) that the subject scaling aims to put individuals on a continuum so that the relative position of individuals according to an measured attribute can be obtained. In addition, this procedure has high practical value and is widely used by designers of psychological scale. This is due to the fact that in the form of scaling of subjects, questions and choice of answers are presented in the form of statements or narrative.

Here are some examples of items on the scale to measure the honesty character of students through mathematics learning in the form of subject scaling produced in this study namely items J4, J9, J13, and J17. These items are items that have the highest SLF value in each component. The following indicators are represented by each item.
Item J4 : Revealing the real situation or not pretending (SLF=0,37).

Item J9 : Not cover up other people mistakes (SLF=0,65).

Item J13 : Not exchanging the result of work with friends $(\mathrm{SLF}=0,78)$

Item J17 : Does not damage or harm other people's ownership $(\mathrm{SLF}=0,60)$

The scoring on a scale to measure the honesty character of students is in the form of subject scaling with three choices of answers in this study are: score 2 for the choice of answers that indicate the most honesty character, score 1 for answer choices that indicate less honesty character, and a score of 0 for the answer choices does not indicate honest character. The following is a description of points $\mathrm{J} 4, \mathrm{~J} 9, \mathrm{~J} 13$, and $\mathrm{J} 17$ along with the scoring guidelines.

Item J4:

After explaining the ways to collect data, suddenly the teacher asks your understanding of the material. You have tried to pay attention to the teacher's explanation but have not fully understood the explanation that was just delivered, then you:

a. Say that you only understand some of it and mention parts that are not understood.

b. Say that you don't understand at all and beg the teacher to explain more clearly.

c. Say to the teacher that you already understand and for the material that you don't understand you will just ask your friends .

Scoring guidelines for item $\mathrm{J} 4$ are score 2 for choice a, score 0 for choice $b$, and score 1 for choice $c$.

Item J9:

You see a friend copy your other friends' data when doing individual tasks to collect data on the ideals and hobbies of classmates. One day, suddenly the math teacher called you to the teacher's office 
and asked about the actions of your friend who copied the work of another friend, then you:

a. Say that you don't know what really happened.

b. Try to cover up your friend's mistakes because you don't want your friend get scolded by the teacher.

c. Say everything that you know.

Scoring guidelines for item $\mathrm{J} 9$ are a score of 1 for choice a, score 0 for choice b, and score 2 for choice c.

Item J13:

When the final exam of mathematics is taking place, suddenly the supervisor comes out of the room and turns out that he hasn't been back in class for a while, then you:

a. Take advantage of the situation to ask friends just to match the answers to be more confident.

b. Stay focused on doing the exam eventhough friends start to get noisy because they try to ask each other .

c. Look around at other friends who ask each other and listen to them.

Scoring guide for item J13 is a score of 0 for choice a, score 2 for choice $b$, and score 1 for choice $c$.

Item J17:

Today you borrowed your friend's math notebook because yesterday you didn't attend the class. When you go home from school, you get drenched by the rain and the book you borrow is a little wet and rips a few sheets on the inside. The next day your friend asks for a notebook that you borrow, then what you do is ...

a. Just be quiet and immediately return it as if nothing happened and will tell only if he found out.
b. Tell that the book is already damaged when you borrow it.
c. Tell the damage that occurs and are willing to repair or compensate it.

Scoring guidelines for item J17 are a score of 1 for choice a, score 0 for choice $b$, and score 2 for choice $\mathrm{c}$.

Through the items with the form of subject scaling, students are expected to provide answers that truly show the true condition of the student's honesty character when facing certain situations as stated in the item. The scale to measure the honesty character of students developed in this study is included in the group of noble characters (good character) at the level of moral feeling (Lickona, 1992). That is, the condition of the character revealed reflects the student's commitment to act honestly. This also corresponds to the taxonomy of the affective domain of Krathwohl, which is until the organization stage. This means that students have formed a value system that is consistent in themselves.

The scale to measure the honesty character of students in mathematics learning produced by this study is very relevant to character education in Indonesia. This scale is certainly very helpful in adding references to teachers and education practitioners. In addition to student affective assessment, this scale can also be used by teachers as a reference for conducting research such as classroom or experimental action research. For other researchers, this scale can be a reference for instruments in the form of psychological scales in the form of subject scaling. This is because this scale is still very rarely developed, especially in the assessment of attitude aspects in mathematics learning.

Scale scoring in this study is still manual, so it requires a relatively long time. Further development can be made in the form of software or presented online so that scoring can be done more easily and quickly. This is like Leachy (2012) who argued that technological development should be used 
by teachers in assessment activities because tech-nology can be designed and utilized to provide a rapid response to student work. Further testing activities also need to be carried out in other areas with larger and heterogeneous respondents so that it further broadens generalizations and adds evidence of the quality of the scale produced by this study. Further development of this scale can also be done on the development of a scale to measure other characters which are the priority of character strengthening activities in the education system in Indonesia.

\section{Conclusion}

This study produces a scale to measure the honesty character of students through mathematics learning with a scale component including: acting according to reality, admit every action whether it is positive or negative, do assignment or exam according to their own abilities, and can be trusted about the ownership of others. The resulting scale consists of 15 items in the form of subject scaling which is theoretically and empirically proven to be of good quality. The quality of the resulting scale is as follows: (1) The validity of the content of the scale is good, supported by the suitability of the items with the indicators in all items are valid with V Aiken index of 0.88-0.92, (2) Scale items to measure honesty characters of the student in overal has good construct validity, and (3) the reliability of the scale to measure the honesty character of students is good with the Omega coefficient of 0.86 .

\section{References}

Aiken, L. R. (1985). Three coefficients for analyzing the reliability and validity of ratings. Educational and Psychological Measurement, 45(1), 131-142. https://doi.org/10.1177/00131644854 51012

Asmani, J. M. (2011). Buku panduan internalisasi pendidikan karakter di sekolah. DIVA Press.

Azwar, S. (2005). Penyusunan skala psikologi (1st ed.). Yogyakarta: Pustaka Pelajar.

Bashir, H., \& Bala, R. (2018). Development and validation of academic dishonesty scale (ADS): presenting a multidimensional scale. International Journal of Instruction, 11(2), 57-74. https://doi.org/10.12973/iji.2018.112 $5 \mathrm{a}$

Bisri. (2009). Akblak. Jakarta: Direktorat Jenderal Pendidikan Islam Agama RI.

Cherrington, J. O., \& Cherrington, D. J. (1979). Honesty and business ethics in the accounting profession. In the Annual Meetings of the American Accounting Association in Honolulu. Hawaii.

Emosda. (2011). Penanaman nilai-nilai kejujuran dalam menyiapkan karakter bangsa. Innovatio, X(1), 151-166.

Ercegovac, Z., \& Richardson, J. V. (2004). Academic dishonesty, plagiarism included, in the digital age: A literature review. College \& Research Libraries, 301-318.

Garson, G. D. (2009). Overview structural equation modeling.

Hair, J. F., Black, W. C., Babin, B. J., \& Anderson, R. E. (2009). Multivariate data analysis (7th ed.). Prentice Hall.

Hooper, D., Couglan, J., \& Mullen, M. R. (2008). Structural equation modelling: Guidelines for determining model fit. Electronic Journal of Business Research Methods, 6(1), 53-60.

Igbaria, M., Zinatelli, N., Cragg, P., \& Cavaye, A. L. M. (1997). Personal computing acceptable factors in small firms: A structural equation model. MIS Quarterly, 279-299.

Kementerian Pendidikan dan Kebudayaan Republik Indonesia. (2013). Modul pelatihan implementasi kurikulum 2013: Materi pelatihan guru implementasi kurikulum 2013 SMP/MTs. Jakarta: Badan Pengembangan Sumber Daya Manusia Pendidikan dan Kebudayaan 
dan Penjaminan Mutu Pendidikan.

Kementerian Pendidikan dan Kebudayaan

Republik Indonesia. (2015). Panduan penilaian untuk sekolah menengah pertama.

Jakarta: Direktorat Pembinaan Sekolah Menengah Pertama.

Koellhoffer, T. (2009). Character education: being fair and honest. New York: Infobase Publishing.

Koss, J. (2011). Academic dishonesty among adolescents. American Psychological Association, 11(2), 38-46.

Krathwohl, D. R., Bloom, B. S., \& Masia, B. B. (1964). Taxonomy of educational objectives: Handbook II: affective domain. New York: David McKay.

Kumaidi. (2014). Implementasi penilaian autentik dalam pembelajaran di kelas. In Seminar Nasional Implementasi Penilaian dan Pelaksanaan Kurikulum 2013. Jakarta: Universitas Negeri Jakarta.

Leachy, G. (2012). QR code in mathematics classrooms. In Mathematics Teaching Issue (Vol. 235, pp. 27-29). Derby: The Association of Teacher of Mathematics.

Lickona, T. (1992). Educating for character. New York: Bantam Books.

Maharani, E. (2016, June). DIY targetkan 25 persen sekolah terapkan K-13,. Republika.Co.Id.

Popham, W. J. (2009). Test better, teach better: the instructional role of assessment. United
States of America: Association for Supervision and Curriculum Development.

Punyanunt-Carter, N. M. (2017). Responseoptions for scales: does it matter what words you use? Journal of Media Critiques, 3(9), 33-49. https://doi.org/10.17349/jmc117103

Schmelkin, L. P., Gilbert, K., Spencer, K. J., Pincus, H. S., \& Silva, R. (2008). A multidimensional scaling of college students' perceptions of Academic Dishonesty. The Journal of Higher Education, 79(5), 587-607. https://doi.org/10.1353/jhe.0.0021

Suranto, Muhyadi, \& Mardapi, D. (2014). Pengembangan instrumen evaluasi Uji Kompetensi Keahlian (UKK) administrasi perkantoran di SMK. Jurnal Penelitian Dan Evaluasi Pendidikan, 18(1), 98-114. Retrieved from https://journal.uny.ac.id/index.php/jp $\mathrm{ep} /$ article/view/2127

Widhiarso, W. (2009). Koefisien reliabilitas pada pengukuran kepribadian yang bersifat multidimensi. Psikobuana, 1(1), 39-48.

Wijanto, S. H. (2008). Structural equation modeling dengan Lisrel 8.8. Yogyakarta: Graha Ilmu.

Yamin, S., \& Kurniawan, H. (2009). Structural equation modeling: belajar lebih mudah teknik analisis data kuesioner dengan Lisrel-PLS. Jakarta: Salemba Infotek. 